\title{
EKSISTENSI TAFSIR AL-MANAR SEBAGAI TAFSIR MODERN
}

\author{
Subhan \\ Pascasarjana UIN Alauddin Makassar \\ Subehang29@gmail.com
}

\begin{abstract}
Abstrak
Tafsir merupakan salah satu ilmu yang dapat memberikan manusia bagaimana dapat mengetahui makna Al-Qur'an yang samar. Karena dalam Al-Qur'an itu sendiri masih ada ayat-ayat yang belum begitu jelas maknanya (mutasyabihat). Dan dengan adanya tafsir ini, manusia dapat memberikan komentar, keterangan, dan mengeluarkan pendapat tentang hal yang tidak disebut atau yang masih umum dan belum terperinci dikemukakan oleh Al-Qur'an. Sehingga dengan hadirnya berbagai macam kitab tafsir, apakah kajian tafisr yang berbentuk tradisional maupun yang bersifat modern. Salah satunya yang telah memberikan sumbangsih yang baik terhadap perkembangan tafsir dan ilmu tafsir adalah sebagaimana yang tertuang dalam kitab tafsir al-Manar yang meruapan bagian dari kitab tafsir modern. Dan penekanan dalam tafsir tersebut adalah menggunakan corak adab alijtima'i.
\end{abstract}

Kata Kunci: Tafsir,Tafsir al-Manar, Tafsir Modern

\begin{abstract}
Interpretation is one of the arts that can teach people how to know the meaning of the Qur'an. Because in the Qur'an itself there are still verses that are not very clear (mutasyabihat). And with these interpretations, people can comment, comment, and comment on things that are not mentioned or that are not yet general and are not given in detail by the Qur'an. So with the advent of various books of interpretation, whether the study of tafisr is traditional or modern. One that has contributed greatly to the development of interpretations and interpretations of science is as found in al-Manar's interpretive text which is a part of modern interpretations. And the emphasis in that interpretation is on the use of al-ijtima'i manners.
\end{abstract}

Keywords: Tafsir, Tafsir al-Manar, Modern Tafsir 


\section{PENDAHULUAN}

Telah menjadi satu kemufakatan para mufassir, bahwasanya seluruh yang termaktub dalam Al-Qur'an itu hakikatnya ajaran yang harus dipegang oleh umat Islam. Ia memberikan petunjuk dan pedoman hidup untuk mencapai kebahagiaan dunia-akhirat dalam bentuk ajaran aqidah, akhlak, hukum, falsafah, siyasah ibadah, dan lain sebagainya. Karena memahami Al-Qur'an itu adalah suatu kewajiban bagi setiap muslim, di mana ia merupakan perintah Allah Swt bagi hambaNya dan risalahNya yang dikirim kepadanya melalui utusanNya, Muhammad saw. Barang siapa tidak membaca dan tidak memahami Al-Qur'an. Berarti dia telah meremehkan risalah Allah Swt dab sekaligus merendahkan siapa yang mengirimnya serta siapa yang diutus membawanya. ${ }^{1}$ Dan hal ini juga perlu ditopang oleh kemampuan memahami dan mengungkap isi serta mengetahui prinsip-sip yang dikandung oleh Al-Qur'an. ${ }^{2}$ Kemampuan seperti inilah yang diberikan tafsir.

Tafsir adalah penjelas atau keterangan yang di dalamnya membahas tentang maksud dan tujuan firman Allah Swt sebatas kemampuan manusia, dan jga sebagai sebuah ilmu untuk memahami kitab Allah yang diturunkan kepada Nabi Muhammad saw, yaitu menjelaskan makna-maknanya serta mengeluarkan hukum dan hikmahnya. ${ }^{3}$

Pada dasarnya, usaha-usaha untuk menafsirkan Al-Qur'an itu sudah dimulai sejak Rasulullah saw. Rasulullah yang mempunyai otoritas dan tugas utama dalam menjelaskan wahyu Allah Swt. Oleh karena itu, penafsiran yang paling benar adalah penafsiran yang diberikan oleh Rasulullah saw. Hanya saja, tafsir Al-Qur'an pada masa Rasulullah belumlah begitu dirasakan, sebab apabila sahabat kurang memahami sebuah ayat, mereka dapat langsung menanyakan kepada Rasulullah. Dan Rasulullah saw selalu memberikan jawaban-jawaban yang maksimal. Setelah Rasulullah saw wafat, para sahabatlah yang melanjutkan perkembangan ilmu ini, kemudian ilmu ini dilanjutkan oleh para tabi'in, tabi' tabi'in serta generasi-generasi yang tumbuh dan hidup pada masa-masa berikutnya.

Tidak diragukan lagi bahwa sejarah tasir Al-Qur'an berlangsung melalui berbagai tahap dan kurun waktu yang panjang, sehingga mentuknya yang disaksikan sekarang ini berupa tulisan yang berjilid-jilid banyaknya, baik yang bercetak maupun yang masih berupa tulisan tangan. ${ }^{4}$ Tiap-tiap masa dan generasi menghasilkan tafsir-tafsir Al-Qur'an yang sesuai dengan kebutuhan dan keperluan generasi itu dengan tidak menyimpang dari ketentuan-ketentuan agama Islam sendiri. Dalam hal ini, ilmu tafsir itu mempunyai pula aliran-aliran dan perbedaan pendapat yang timbul karena perbedaan pandangan dari segi meninjaunya. Dengan kata lain, mempunyai metode dan corak tersendiri di dalam menafsirkan

${ }^{1}$ Ni'mat Sidqy, Nikmat Al-Qur'an (Cet. 3; Bandung: Husaini, 2000), h. 20.

${ }^{2}$ H. Nasaruddin Umar, Deradikalisasi Pemahaman Al-Qur'an \& Hadis (Cet. 1: Jakarta: Rahmat Semesta Center, 2008), h. 11.

${ }^{3}$ Muhammad Chirzin, Al-Qur'an dan Ulumul Qur'an (Cet. I; Jakarta: Dana Bhakti Prima Yasa, 1998), h.5.

${ }^{4}$ Subhi Soleh, Mabahis Fi ulumil Qur'an (Cet. I; Jakarta: Dinamika Berkah Utama, t.th.), h. 289 . 
Al-Qur'an. Seperti dalam kitab tafsir al-Manar sebagai sebuah kitab tafsir yang modern.

\section{PEMBAHASAN \\ a.Kilas Balik Tafsir Al-Manar}

Tafsir Al-Manar yang bernama Tafsir Al-Qur'an Al-Hakim memeprkenalkan dirinya sebagai kitab tafsir satu-satunya yang menghimpun riwayat-riwayat yang sahih dan pandangan akal yang tegas, yang menjelaskan hikmah-hikmah syariah, serta sunnatullah (hukum Allah yang berlaku) terhadap manusia, dan menjelaskan fungsi Al-Qur'an sebagai petunjuk untuk seluruh umat manusia, disetiap waktu dan tempat, serta membandingkan antara petunjuknya dengan keadaan kaum muslimin dewasa ini, serta membandingkan pula dengan keadaan para salaf (leluhur) yang berpegang teguh dengan tali hidayah itu. Tafsir ini disusun dengan redaksi yang mudah sambil berusaha menghindari istilahistilah ilmu dan teknis sehingga dapat dimengerti oleh orang awam tetapi tidak dapat diabaikan oleh orang khusus (cendekiawan). ${ }^{5}$

Kitsb tafsir al-Manar bermula dari kuliah tafsir al-Qur'an yang diberikan oleh Muhammad Abduh di Universitas al-Azhar, Mesir, yang berlangsung dari tahun 1899 M hingga ia wafat pada tahun 1905. Kuliah-kuliah tersebut selalu dihadiri oleh Rasyid Ridha, murid Muhammad Abdh yang setia, ia mencatat keterangan dan penafsiran setiap atayat yang disampaikan oleh gurunya. Kemudian catatan-catatan tersebut disusunnya dalam bentuk tulisan yang teratur dan diserahkan kepada gurunya untuk diperiksa. Setelah mendapat persetujuan, tulisan tersebut diterbitkan dalam majalah al-Manar. Tulisan-tilsan tersebut kemudian dibukukan dan dikenal dengan nama Tafsir al-Manar. ${ }^{6}$

Tampak sekali, bahwa Muhammad Abduh dan Rasyid Ridha dalam menciptakan sebuah kitab tafsir modern yang sampai sekarang masih menjadi sebuah refernsi atau dalam landasan dalam memhami tafsir Al-Qur'an dengan baik dan benar, tentunya kedua pengarang tafsir al-Manar tersebut tampil untuk memperjuangkan eksistensi umat Islam pada saat itu untuk senantiasa mempunyai pemikiran yang maju, khususnya dalam dunia kajian tafsir Al-Qur'an.

\section{b.Tafsir Al-Manar Sebagai Tafsir Modern \\ 1.Metode Tafsir al-Manar}

Sebagai sebuah kitab tafsir yangb lahir di abad modern, tentunya pengarang tafsir al-Manar dalam menafsirkan ayat-ayat aAl-Qur'an memakai suatu metode penelitian tafsir yang telah ada. Yaitu metode yang telah dipergunakan oleh para ulama tafsir sebelumnya dan sudah masyhur dikalangan para mufassir baik salaf maupun khalaf.

Dalam menentukan sebuah metodologi penafsiran pada salah satu kitab tafsir, maka terlebih dahulu diadakan suatu penelitian pada kitab tersebut. Agar supaya dalam penetuan metode yang dipergunakan pada sebuah kitab tafsir dapat 2002), h. 67

${ }^{5}$ M. Quriash Shihab, Studi Kritis Tafsir Al-Manar (Cet. 3; Baadung: Pustaka Hidayah,

${ }^{6}$ H. Kafrawi Ridwan, Edit. Ensiklopedi Islam. Juz. 3 (Cet. 9: Jakarta: Ichtiar Baru Van Hoeve, 2000), h. 151. 
jelas dan bisa di pahami. Dan setelah diadakan suatu pelitian, mufassir berpendapat bahwa metode dipergunakan oleh Rasyid Ridha dalam kitab tafsirnya dalam menafsirkan ayat-ayat Al-Qurán adalah metode tahlili dan analisis.

Metode tafsir tahlili atau analisis adalah suatu metode tafsir yang mufassirnya berusaha menjelaskan kandungan ayat Al-Qurán dengan menganilisis secara kronologis dari berbagai seginya, dengan memperhatiakn tuntunan ayatayat sebagaiman yang tercamtum dalam mushaf Usmani. ${ }^{7}$ Sedang segi-segi yang menjadi perhatian utama dalam metode ini adalah berkaitan dengan penjelasan soal makna dan kandungan ayat, interelasi ayat dan surat, asbab al-nuzul (latar belakng turunnya ayat), pendapat pra mufassir terdahulu, disamping penilain mufassirnya sendiri yang mungkin diwarnai oleh latar belakang pendidikan dan keahliannya.

Tentang penggunaan metode tahlili atau analisis ini, Rasyid Ridha dalam menafsirkan ayat-ayat Al-Quran memakai sistem penfsiran secara mustawah (pertengahan). Di samping itu mufassir lainnya ada yang menempuh dengan sistem penfsiran secara ithnab ( panjang lebar) dan sistem ijaz (singkat). Dan bukti singkat sebagai penguat bahwa kitab tafsir al-Manar karya Muhammad Rasyid Ridha tersbeut memakai meotde tahlili atau analisis, diantaranya dalam penafsiran ayat surat Al- An'ám (bab III hal 96-98). Dalam menafsirkan ayat tersebut, pada awalnya beliau terlebih dahulu menghubungkan dengan ayat-ayat sebelumnya setelah itu barulah ditafsirkan secara ayat per-ayat.

Untuk mendapatkan penafsiran yang jelas pada ayat tersebut, pertama beliau mengeluarkan makna yang terkandung dalam ayat. Dalam hal ini, menguraikan kosa kata dan lafadh, menjelaskan artiyang dikehendaki, sasaran yang dituju dan kandungan ayat. Seperti lafadh kata disinitidak termaksud janji Allah dalam pelipat gandakan atas segala sesesatu atas sebagian amal seperti infaq dijalanNya. Dan allah telah menjanjikan secara langsung pelipat gandaan, sebagaimana pada penejlasan surat sebelumnyadan sesudahnya. (suart Al-Baqarah ayat 245 dan ayta 261 seta surat Al-Thagabun ayat 17).

Sedang pada lafadh beriktnya, beliau menafsirkan secara langsung terhadap apa yang dikandung pada kalimat tersebut. Yaitu bahwa sahnya sifatsifat buruk yang ada dalam jiwanya kufur penuh dengan kekejiqn dan kemungkran, maka tidak akan mendapat balasan kecuali akibat dari perbuatan jeleknya sesuai dengan sunnahnya dalam ketentuan perbuatan-perbuatan buruk di dalam menipu dirinya, merusak dirinya dan ketentuan balasan baginya adalah dengan adil.

Demikan pula pada lafazh terakhir, beliau menafsirkannya dengan merujuk pada hadis Raslullah SAW, yaitu aspa yang diriwayatkan oleh imam muslim dari Abu dzar R.A Rasulullah SAW sebagaimana yang diriwayatkan oleh tuhannya : "Hai hamba-hambaku, sesungguhnya aku telah, mengharamkan kedholiman bagi jiwaku dan aku telah membuat antara kalian penyehat, maka janganlah salin mencela."

7 Khoruddin Nasution, Pengantar Studi Islam (Yogyakarta: ACAdeMIA+TAZZAFA, 2012), h. 122 . 
Adapun pada penafsiran ayat20 surat At-Taubah (Bab III hal 99-100), beliau terlebih dahulu mengeluarkan makna yang terkandung dalam ayat tersebut. Dalam hal ini menuju pada penafsiran ayat dengan menonjolkan kandungan lafadz-lafadznya. Setelah ayat tersebut dapat diketahui dan dipahami, beliau lalu menafsirkannmya dengan membahas lebih awal pada masalah jihad. Dimana apabila seorang hamba berhijrah dengan jihat yang benar, yaitu jihad di jaln Allah SWT, maka bginya akan mendapatkan suatu derajat yang tinggi. Demikian pula sebaliknya bagi hamba bagi hamba yang berjihad di jalan yang tidak benar. Dan setlah jihad itu dilakukan dengam benar, maka bagi seorang hambat itu akan mendapatkan pyula suatu kemenangan dan hasil jihat itu, yaitu adnya suatu perlindungan dari Allah SWT yang maha mulia karamahnya.

Sedangkan penafsiran ayat 22 surat Yusuf ( Baba III 100-103), penafsiran Rasyid Ridha lebih cenderung pada penafsiran aqliyah. Diman ayat ditafsirkan dengan kalimat bahwa apabila seseorang itu sudah tumbuh dewasa dengan fisik yang baik akan diberikan suatu hikam dan ilmu. Dalam hal ini, usia dewasa di sini ada berbagai macam pendaopat. Ada yang 25 tahun, 33 tahun dan 40 tahun. Dan yang termasyhur adlah umur 40 tahun. Hal ini juga sam apa yang dialami oleh rasulullah SAW ketika diangkat menjadi Rasul Oleh Allah SWT (umur 40 tahun). Dan pada penfsiran teralhir, ini di sesuaikan dengan makna yang terkandung dalam kalimat tersebut. Yaitu dari urusuan kitalah yang menberikan kepada orang sukses dengan sifat kebaikan yang telah menyelesaikan amalnya.

Demikian pula pada penfsiran ayat 62 surat Al-An'am ( Bab III hal. 103106) beliau menfsirkannya dengan menuju naqliyah, yaitu dimana ada penafsiran sesuai dengan apa yang terkandung dalam bunyi ayat tersebut. Seperti lafadz, bahwa Allahlah yang merupakan raja yang haq untuk menghisab setiap insan yang ada di mjuka bumi ini. Dalam hal ini hukum yang tertinggi ada pada kekuasaan Allah SWT. Dan dari akhir ayat, ini di tafsirkan bahwa hukum penghisaban dari Allah Swt itu tidak bisa di undur dan ditangguhkan, tetapi akan mempercepat perhitungan tersebut. ${ }^{8}$

Dari penafsiran ayat belaiu diatas yamh bermetodekan tahlili atau analisis, tidak dapat terselesaikan secara keseluruhan (30 juz). Hal ini di sebabkan beliau meninggal sebelum menafsirkan ayat-ayat Al-Qurán secara penuh. Dan hanya menafsirkan sampai ayat 52 surat yusuf.

\section{Corak Tafsit al-Manar}

Untuk memdapat suatu penafsiran yang baik dan jelas serta dapat dikenal dan diterimah oleh orang- orang yang ingin mendalami tafsir $\mathrm{Al}=\mathrm{Qur}$;an. Mak masing-masing mufassir, dalam hal ini bagi para pengarang kitab tafsir baik yang salaf maupun yang khgalaf mempunyai suati corak atau tipe tersendiri di dadalam menafsirkan ayat-ayat al-Qurán. Seperti apa yang di tempuh oleh Muhammad Ridha Rasyid.

Setelah diadakan suatu penelitian, bahwa sahnya dalam tafsir al-manar karya muhammad Rasyid Ridha. Terdapat berbagai macam corak tafsir yang dipergunakan dalam menafsirkan ayat-ayat Al-Qur'an. Adapu corak atau tipe tafsir tersebut di anataranaya adalah: Corak Tafsir Ilmiah, yaitu menjelaskan

${ }^{8}$ Azzahabi, Tafsir Wal Mufassirun, Juz. III (Beirut: Darul Fikr, t,th,), h. 577. 
isyarat-isyarat Al-Qur'an mengenai gejala alam yang bersentuhan dengan wujud Tuhan yang Maha Hidup dan Maha Kuasa. ${ }^{9}$

Dalam penggunaannya pada kitab tafsir al-Manar didasarkan pada kesesuaian dengan sosial kultural, perkembangan ilmu serta adab dan budaya yang mengalami kecemerlangan sehingga Rasyid Ridha banyak sekali mengkaji Al-Qur'an dengan berbagi macam ilmu displin. Sebagaimana dengan adanya terdapat dalam surat al-fatiha yang mengandung berbagai macam aspek pengetahuan. Memcapai kebahagian, dan kisah-kisah umat masa dahulu.

Di samping itu, Rasyid Ridha juga ahli dalam bidang hadis dan fiqhi. Sebagaimana krtik-kritiknya terhadap gurunya imam Muhammad Abduh dengan dengan didasarkan pada argumentasi hadis-hadis. Seperti pada masalah penciptaan adam. Menurut Muhammad Abduh terbetuk tiga fitrah manusia, yaitu masa kanak-kanak, tamyizdan dewasa. Sedangkan menurut rasyid ridha sendiri, hal tersebut adalah manusia yang berkedudukan sebagai makhluk sosial.

Corak Tafsir Adab Ijtimai, yaitu mengungkapkan isi kandungan AlQur'an dimana kata-kata majemuk itu dianalisis berdasarkan nahwu dan balagah dengan penggunaan ilmu yang tidak boleh melewati batas, hanya untuk mengungkapkan keindahan sastra pada teks. ${ }^{10}$ Dan dalam kajian ini, Muhammad Rasyid Ridha berusaha mengkaji sunnah ijtimai'iyyah ( hukum-hukum mengkaji sunnah kemasyarakatan) dalam Al- Qur'an untuk mendorong kepada kemakmuran dan kemajuan masyarakat islam. Dalam hal ini, nilai-nilai sosial perlu ditiumbuhkan dan sebab-sebab kemundurannya karena tidak adanya nilai sosial yang terkandung di dalam nya.

Disisi lain, beliau juga berusaha untuk menmgembangkan pembahasan sunnahtullah sebagai wujud reaksi adanya modernisme dalam memjawab kelemahan umat islam dan memperbaharui sosial kultural umat islam. Dan dari corak tafsir atau tipe tafsir yang dipergunakan Muhammad Rasyid Ridha dalam tafsirnya al-manar, tipe yang paling dominan. Karena tipe tersebut cukup bermutu yntuk mendorong pembangunan dan kemajuan masyarakat islam ditengah-tengah pergolakan umat islam menghadapi bangsa lain.

\section{Pendapat Ulama Tentang Tafsir al-Manar}

Tafsir modern tentang Al-Qur'an adalah usaha untuk menyesuaikan ayatayat dengan tuntutan zaman, dan hal itu benar-benar terjadi suatu keharusan sejak wafatnya nabi Muhammad SAW sejak kekuasan beralih ke khalifaan (khulafaur Rasyidin) sitausinya berkembang dalam kondisi yang berbeda dengan zaman nabi. dengan pada zaman nabi. Karena itu berbagai pemikiran yang terkandung dalam al-Qur'ān segera dirasakan membutuhkan penafsiran ulang. Tuntunan ini dirasakan perlunya setelah sentuhan dengan peradaban ekspansi asing menjadi kian intensif, justru melalui muslimin sendiri yang berlangsung kaum kekuasaan sangat cepat.

Sesungguhnya gerakan tafsir modern memainkan peran yang menentukan dalam memajukan kesadaran berpolitik menurut pandangan Islam,

\footnotetext{
${ }^{9}$ Samsurrohman, Pengantar Ilmu Tafsir (Cet. I; Jakarta: AMZAH, 2014), h. 190.

${ }^{10}$ Samsurrohman, Pengantar Ilmu Tafsir 202.
} 
dan memotivasi manusia untuk ber juang demi membela kebenaran dan keadilan. Begitu hebat dan dahsyat perlawanan yang diberikan oleh pengikut al-Manar terhadap penjajah, tanggung jawab para pemimpin negara-negara dan Islam juga begitu besar terhadap musibah, kesengsaraan, dan negara-negara Islam oleh penjajah.

Tafsir al-Karim atau al-Qur'an "Tafsir al-Manar" merupakan salah satu dengan nama peminat dan populer dikalangan para tafsir modern studi Islam, khususnya tentang tafsir al-Qur'ān. Kitab tafsir al-Manar adalah satu-satunya kitab dan shahih menghimpun riwayat-riwayat yang yang akal yang tegas, yang menjelaskan hikmah- yang pandangan syari'ah, serta sunnatullah (hukum Allah hikmah manusia, dan menjelaskan fungsi- terhadao berlaku) al-Qur'an sebagai petunjuk untuk tempat, seluruh fungsi serta dan waktu disetiap manusia, antara petunjuknya dengan keadaan diterbitkannya) kaum membandingkan yang dewasa ini (pada masa muslimin serta itu, petunjuk dari berpaling telah salaf para pula) dengan keadaan (membandingkan hidayah berpegang teguh dengan ini disusun dengan redaksi yang tall (leluhur) yang mudah Tafsir itu. dan berusaha menghindari istilah-istllah ilmu sambil teknis sehingga dapat dimengerti oleh orang tidak dapat diabaikan oleh orang-orang awam tetapi khusus (cendekiawan).

Muhammad Abduh dan semua generasi pendukung mażhab pemikirannya di dalam tafsir, menempuh jalan yang benar. Mereka mengambil contoh-conth budaya yang tetapi tidak meninggalkan kaidah-kaidah aktual lama. menyelamatkan Untuk dilema timbul yang akibat kontradiksi antara pendapat lama dan pendapat tersebut, pintu ijtihad sangat mendesak untuk baru dibuka. Disinilah Muhammad Abduh mażhab penafsirannya dan telah melaksanakan sempurna hal itu. Persoalan- persoalan ijtihad yang banyak muncul dari lingkungan dan para ahli tafsir telah banyak dipengaruhi Islam oleh pemikiran ini.

Suasana semacam itu, tafsir juga banyak Dalam diwarnai dengan arah politik yang berlaku pada masanya dan tuntutan-tuntutan perkembangan budaya. Penguraian Abduh atas al-Qur'än dilanjutkan oleh Rasyid Ridha, muridnya sendiri, yang Muhammad memang Orientalis, mendapat perhatian para sepatutnya analisa yang sekali dari J. Jomier, karena terutama ditunjukkan Ini kena dan mendalam. dilakukan cukup oleh cara mereka mengemukakan tidak terlalu menyimpang Menurut pendapat berlaku. dari metode yang biasa terhadap hal yang membedakan ulasan Abduh saya, Qur'ān adalah keinginannya yang nyata untuk memberikan untuk ayatnya memungkinkan bilamana ajaran moral itu.

Setelah kedua pengarang tafsir al-Manar tiada, banyak kaum modernis Islam yang ingin mempelajari dan rendalami kitab tafsir tersebut. Khususnya para Ulama Tafsir dan bagi mereka yang mendalami ilmu tafsir. Hal ini dikarenakan tafsir tersebut mempunyai suatu corak tersendiri di dalam menafsirkan ayat-ayat al-Qur'an. Di nana corak tersebut dapat memberikan suatu petunjuk dalam kehidupan masyarakat dan usaha-usaha untuk problem-problem mereka nenanggulangi penyakit atau berdasarkan ayat-ayat al-Qur'ān serta bahasa indah dan menarik yang dapat membuat pembaca terpesona kedalam kalbunya, sehingga tergugah yang serta merasuk hatinya untuk memperhatikan Kitabullah dan timbul minat serta gairah untuk mengetahui segala makna dan rahasia al-Qur'än al-Karim tersebut. 
Kitab tafsir al-Manar sebagai salah satu tafsir modern yang muncul pada awal abad ke-20, tersebar luas keseluruh pen juru dunia islam dan mempunyai peranan yang besar dalam pencerahan pemikiran serta penyuluhan Dan hal ini menberikan suatu komentar atau agama. pendapat tersendiri bagi Ulama Tafsir terhadap tafsir al-Manar tersebut. Dalam hal ini, para ulama ada yang memujinya dan mengkritiknya.

a.Pandangan Ulama Yang Memuji

Hamka dalam kitabnya "Tafsir al-Azhar" dengan mengatakan : "Tafsir yang amat menarik hati penafsir ini buat dijadikan contoh ialah tafsir "al-Manar" karangan Sayyid Rasyid Ridha, berdasar kepada ajaran tafsir gurunya Syaikh Muhammad Abduh. Tafsir beliau ini, selain dari menguraikan ilmu yang berkenaan dengan agama, hadis dan fiqhĩ, sejarah dan lain-lain, menyesuaikan ayat-ayat itu dengan bangan politik dan kemasyarakatan, yang sesuai dengan zaman di waktu tafsir itu dikarang. Meskipun tafsir itu beliau tulis hanya 12 saja, artinya tidak sampai separuh al-Qur'an namun dia dapat dijadikan pedoman di dalam meneruskan penafsiran "al-Azhar" ini sampai tamat. Meskipun soal-soal kemasyarakatan dan politik dunia Islam yang waktu itu, di zaman sekarang ini sudah banyak berubah, karena perubahan yang terjadi dalam negeri-negeri Islam, namun dasar penafsiran yang beliau tegakkan masih tetap, hangat dan dapat dicontoh, dan tidak basi". ${ }^{11}$

Menurut Subhi Sholeh dalam kitabnya "Mabahis FI Ulūmil Qur'an" mengatakan : "Adapun Kitab tafsir al-Manar karya Sayyid Muhammad Rasyid Ridha, merupakan tipe khusus dalam menta'wilkan firman Allah Swt. yang pada galibnya tafsir tersebut ditulis berdasarkan hadis-hadis pusaka kaum salaf, kemudian diusahakan penyesuaiannya dengan zaman kita dewasa ini. Dalam banyak hal demikian itu berhasil, meskipun penulisannya terasa kelewat teguh berpegang pada pendapat yang lemah namun dibela dengan segala tampak jelas bahwa penulisnya secara umum memiliki pengetahuan secara mendalam mengeiinal metode al-Qur'an yang dipelajari sebagai Kitab Suci pembawa hidayah dan i'jaz". ${ }^{12}$

Manna' al-Qaththan Menurut dalam kitabnya "Mabāhis Fi Ulūmil Qur'ān" mengatakan : "Tafsir al-Manar adalah sebuah tafsir yang penuh dengan pendapat para pendahulu ummat ini, sahabat dan tabi'in dan penuh pula dengan uslub-uslub bahasa Arab dan penjelasan tentang sunnatullah yang berlaku dalam kehidupan ummat Ayat-ayat al-Qur'an ditafsirkan manusia. dengan gaya bahasa diungkapkan dengan dipahami, berbagai menarik, redaksi makna-makna mudah dijelaskan tuduhan dan kesalah pahaman pihak musuh yang dilontarkan terhadap Islan dibantah dengan tegas dan penyakit-penyakit masyarakat ditangani, diobati dengan petunjuk qur'āni. Syaikh Rasyid Ridha menjelaskan bahwa memahami Kitabullah sebagai sumber ajaran agama yang membimbing ummat manusia kearah kebahagiaan yang persoalan secara tuntas, tujuan pokok penafsirnya, ialah hidup di dunia dan hidup di akhirat". ${ }^{13}$

\footnotetext{
${ }^{11}$ Hamka, Tafsir Al-Azhar, Juz. 1 (Jakarta: Pembimbing Massa, 1990), h. 37.

${ }^{12}$ Subhi Sholeh, Mabahis Fi Ulumil Qur'an, h. 297.

${ }^{13}$ Manna' al-Qattan, Mabahsi Fi ulumil Qur'an (Kairo: Mansurat al-Asr al-Hadis, t.th.),
} h. 372 . 


\section{b.Pandangan Ulama yang Mengkritik Menurut}

M. Qurainh Shihab "Studi Kritis Tafsir al-Manar" mengatakan : dalam karyanya "Syaikh Muhammad Rasyid Ridha adalah mufassir yang terlalu berani dalam menggunakan teori-teori seorang mendukung untuk 11 miah penafsirannya. Sehingga terkadang dirasakan adanya usaha menbenar-benarkan teori ilmiah, sekalipun yang belum mapan dengan ayat-ayat al-Qur'an. menilai para mufassir, selain gurunya Muhammad Abduh. Mufassir lain di kecam dengan anat keras dan pedas, dan terkadang nukilannya tidak sesuai dengan maksud pendapat mufassir yang dinukil. Seperti kecamannya Fakruddin ar-Razi yang dicap sebagai mufassirr yang kurang pengetahuannya tentang as-aunnah, pendapat-pendapat para sahabat, serta tokoh- tokoh salaf dibidang tafsir dan hadis". ${ }^{14}$

Menurut M. Baqir ash-Shadr "Pedoman Tafsir Modern" mengatakan: "Mufassir memulai aktifitas penafsirannya, dengan teratentu, misalnya suatu ayat atau kalimat, tanpa pemikiran, kemudian membatasi konsep al-Qur'ān yang berkaitan dengan dasar pemikiran yang telah dirumuskannya. Juga penafsiran yang kepada masyarakat Islam. Dengan tujuan untuk menarik pengikut dan pendukug mażbahnya. Hal ini bersumber dari metodologi yang dipergunakan oleh si penafsir". ${ }^{15}$

Menurut Abdul Rahman al-Baghdady dalam kitabnya "Nazharatun Fi Tafsir al-Ashry lil Qur'ānil Karīm" mengatakan : "Dengan adanya penonjolan teori-teori ilmiah dalam penafsirannya, maka akan menimbulkan suatu anggapan bahwa al-Qur'än itu mencakup seluruh ilmu pengetahuan. Dengan tujuan untuk memperkokoh teori-teori ilmu pengetahuan modern dan untuk memastikan bahwa sebelum itu al-Qur'ān. merupakan dikemukakan oleh sudah semuanya Pada sebenarnya,pemahaman yang dangkal dan kebekuan berfikir. jauh lagi, yaitu dapat kesesatan dan penyelewengan yang Maha Bahkan lebih menimbulkan karena tidak menghiraukan kebenaran bersumber Mengetahui semesta, tentang manusia, segala kehidupan dan Yang Maha Pencipta dan segala pada alam sesuatu tentang yang berada di luar alam wujud, akibat semua sikap mereka yang membuntut di belakang teori-teori ilmu pengetahuan yang bersumber pada akal manusia yang serba kurang, terbatas dan tidak mengetahui segala sesuatu". ${ }^{16}$

Dengan demikian, bahwa setiap kitab tafsir yang ditulis oleh para mufassir, baik itu mufassir salaf maupun khalaf, tentunya mempunyai suatu pujian ataupun kritik yang bersumber dari para ulama. Hal ini dikarenakan adanya pemikiran para mufassir itu didipengaruhi oleh banyak faktor, seperti latar tingkat intelegensi, kecenderungan pribadi, ilmu perkembangan bahkan pendidikan, belakang pengetahuan dan kondisi sosial masyarakatnya. Dalam telah penulis hal ini khususnya kitab tafsir yang bahas di atas, yaitu kitab tafsir al-Manar.

\section{C.PENUTUP}

${ }^{14}$ M. Quriash Shihab, Tstudi Kritis afsir Al-Manar(Cet. I; Bandung: Pustaka Hidayah, 1994), h. 103.

15 M. Baqir Assadr, Pedoman Tafsir Modern (Cet. 1; Jakarta: Risalah Massa, 1992), h. 18.

${ }^{16}$ Abdul Rahman, Nazaratun Fi Tafsir al-ASri Lil Qur'anil Karim (Bandung: Al-Ma'arif, 200), h. 58 . 
Tafsir al-Manar merupakansalah satu kitab tafsir yang lahir diabad modern. Kitab ini ditulis oleh dua mufassir yang masyhur dikalangan umat Islam, yaitu Muhammad Abduh dan Rasyid Ridha. Dalam pemahaman pemikiran atau penafsiran yang dihasilkan oleh Syaikh Muhammad Abduh dan Rasyid Ridha dalam kitabnya tafsir al-Manar, adalah adanya suatu hal yang amat menarik hati ummat karena mudah dicerna oleh kaum awam dan dibutuhkan oleh kaum khawas. Tafsir ini dengan juga penuh pendapat para pendahulu ummat, sahabat dan tabi'in dan penuh pula dengan unlub-uslub bahasa arab dan pen jelasan tentang Sunnatullah yang berlaku dalam kehidupan ummat manusia. Dan menerangkan eksistensi al-Qur'än bagi manusia disegala zaman dan tempat. Kitab ini pula mempertemukan antara hidayah llahi dengan kewajiban yang harus dilakukan oleh kaun munlimin pada masa dewasa ini, dimana masa telah banyak diantara kita meninggalkan hidayah dan ajaran agama yang menjadi pegangan teguh para pendahulu di lampau. Tafsir ini juga berusaha kelemahan kitab-kitab tafsir sebelumnya salalu metode masa terhindari budaya kemasyarakatan dan dengan menetapkan prinsip- prinsip baru serta menjabarkannya secara lebih jelas dibanding dengan tafsir-tafsir sebelumnya.

Demikian pula pada sisi lain, kitab tafsir al- Manar tersebut tentunya mempunyal suatu hal tertentu yang sulit dihindari oleh setiap penafsir. Yaitu adanya kekurangan atau kelenahan di dalam menafsirkan ayat-ayat al-Qur'in. salah satunya adalah fanatisme mazhab dan terlalu berani dalam menggunakan teori-teori ilmiah untuk mendukung penafsirannya. Sehingga terkadang dirasakan adanya usaha teori ilmiah, sekalipun yang belum mapan dengan ayat- menbenarbenarkan ayat al-Qur än.

\section{DAFTAR PUSTAKA}

Azzahabi, Tafsir Wal Mufassirun, Juz. III. Beirut: Darul Fikr, t,th,

Al-Qattan, Manna'. Mabahsi Fi ulumil Qur'an. Kairo: Mansurat al-Asr al-Hadis, t.th..

Assadr, M. Baqir. Pedoman Tafsir Modern. Cet. 1; Jakarta: Risalah Massa, 1992.

Chirzin, Muhammad. Al-Qur'an dan Ulumul Qur'an. Cet. I; Jakarta: Dana Bhakti Prima Yasa, 1998.

Hamka, Tafsir Al-Azhar, Juz. 1. Jakarta: Pembimbing Massa, 1990.

Nasution, Khoiruddin. Pengantar Studi Islam. Yogyakarta: ACAdeMIA+TAZZAFA, 2012.

Rahman, Abdul. Nazaratun Fi Tafsir al-ASri Lil Qur'anil Karim. Bandung: AlMa'arif, 200.

Ridwan, H. Kafrawi. Edit. Ensiklopedi Islam. Juz. 3. Cet. 9: Jakarta: Ichtiar Baru Van Hoeve, 2000.

Samsurrohman, Pengantar Ilmu Tafsir.Cet. I; Jakarta: AMZAH, 2014.

Sidqy, Ni'mat. Nikmat Al-Qur'an. Cet. 3; Bandung: Husaini, 2000.

Soleh, Subhi. Mabahis Fi ulumil Qur'an. Cet. I; Jakarta: Dinamika Berkah Utama, t.th. 
Shihab, M. Quriash. Studi Kritis Tafsir Al-Manar. Cet. 3; Baadung: Pustaka Hidayah, 2002.

Umar, H. Nasaruddin. Deradikalisasi Pemahaman Al-Qur'an \& Hadis. Cet. 1: Jakarta: Rahmat Semesta Center, 2008. 